\title{
The Role of Anti Corruptions Strategies in Combating Corruption
}

\author{
Shalini Kumar \\ Research Scholar Techno India University, Kolkata
}

\begin{abstract}
: "just as it is impossible to know when a fish moving in water is drinking it, so it is impossible to find out when government servants in charge of undertakings misappropriate money"(kautilya, te Arthashastra.2.9.33). From as far back in the 4th century B.C. as Kautilya's Arthashastra to the Saradha Group financial scandal in the contemporary period, corruption in India is a topic which seems to never fall out of focus and is widely perceived to be an common phenomenon. In combating corruption the Indian government's track record has not been very effective If We go through the newspaper \& switch on television most hard-hitting headlines have been about scams, cases of graft, widespread corruption, cheating \& bribery and whistle-blowers. Corruption has become a prominent issue \& progressively increasing in almost every sector in India. Our society itself provides support and nourishment for prevalence and explosion of corruption. At one time bribe was given to getting wrong/unethical things done but now bribe is also paid for getting right things done at right time. The objective of the study is to review the existing anti corruptions strategies, \& why these measures \& initiatives of Indian government in combating corruption have not been able to give desired results.
\end{abstract}

Keywords: Corruption, Anti corruption strategies, scam \& scandals.

\section{Introduction}

The country, which we adore so much has been in the clutches \& wicked jaws of the virus, named Corruption and is widely perceived to be a common phenomenon. From as far back in the 4th century B.C. as Kautilyaes Arthashastra to the Saradha Group financial scandal in the contemporary period, corruption in India is a topic which seems to never fall out of focus. Cause of mostly failure in India is Corruption It has spread in every sphere of life In fact; there is hardly any sector which can be characterized for not being infected with the vices of corruption. Every developmental projects are being over shadow by the corrupt officials. Even the axis of the law i.e magistrates are corrupted to such a degree that millions of cases are pending for the last few years. Today each individual is totally lost in the midst of lucrative attraction prevailing in society, the established social structure and social environment are the true forces that induce corruption.

\subsection{Forms through which corruption operates in system}

a) Bribery: In Encyclopedia of the social Sciences Harold D. Lasswell has defined bribery as "A complicated society abounds in agency relations which increase the opportunity for appeals to private interest, since operations which the individual was once able to perform for himself pass through intermediaries, each one of which is a relay of potentially distorting private motives". There are many equivalent terms to bribery, like kickbacks gratuities , "commercial arrangements", baksheesh, sweeteners ,pay- offs, speed-And grease money, which are all notions of corruption in terms of the money or favours paid to employees in private enterprises, public officials, and politicians.

b) Graft: Graft only requires that the official gains something of value, which is not part of his official pay while doing his work. Thus large expensive gifts qualify as grafts whose values fall much beyond the permissible limits as allowed by the service conduct rules of civil servants.

c) Extortion: Sometimes bribes may also be demanded by corrupt government officials who otherwise threaten to make illegitimate use of state powers in order to inflict harm.

d) Patronage: It refers to showing undue favors to supporters in lieu of their support. This holds particularly true in case of ministers who often bend recruitment rules to provide government employments to his supporters.

e) Nepotism: J.S Nye has defind it as "bestowal of Patronage by reason of ascriptive relationship rather than merit" The Indian equivalent of nepotism is known as "Bhai Bhatijavad" which is a Hindi word implying favoring brothers and nephews.

f) Cronyism: When public office is used by a bureaucrat to show special favor to a friend in lieu of some personal gain or profit.

g) Embezzlement: Also known as misappropriation it is the outright theft of entrusted government fund by government officials. It amounts to misappropriation of government property for private regarding uses by government servants.

\subsection{Scams \& Scandals}

The period of Post-liberalization, Indian economy has witnessed several scams like Harshat Mehta Scam in 1992, Fodder Scam of 1996, UTI Scam of 2001, Satyam Scandal ,the $2 \mathrm{G}$ scam most recently Saradha Group financial scandal in the contemporary period. These scams have just not led to the loss of millions of rupees but have also affected the economy in a major way. These economic crimes and the scale \& the way in which these crimes have been committed are a serious alarm to the Government as well as to the people.

Some of the below listed scams are well known, but some 


\section{International Journal of Science and Research (IJSR) \\ ISSN (Online): 2319-7064}

Index Copernicus Value (2013): 6.14 | Impact Factor (2014): 5.611

may really surprise us with their size, the amount mentioned in the scams in appropriation collected the numbers from various sources.

- Bihar fodder scam: ₹ 9.5 billion (US\$140 million)Bihar ex CMs Lalu Prasad Yadav (Rashtriya Janata Dal), Jagannath Mishra (ex-Indian National Congress) and Lok Sabha MP Jagdish Sharma (Janata Dal (United)) have been convicted in fodder scam. Lalu Prasad Yadav and Jagdish Sharma have also been disqualified from the parliament for corruption.

- 2009 Satyam Computer Services scandal: In this biggest scam ever to hit India's IT sector, Chairman of Satyam Computers, B Ramalinga Raju, admitted to doctoring the company's balance sheets. In a letter written to the board, Raju admitted that he inflated the balance sheets to show Rs 5,361 crore at the end of September 2008, which was over 300 crore more than the actual amount.

\begin{tabular}{|c|c|c|c|c|c|}
\hline \multicolumn{6}{|c|}{ Notable scandals in India } \\
\hline Scandal & $\underset{\text { reported }}{\text { Year }}$ & $\begin{array}{l}\text { Scope INR } \\
\text { Crore }\end{array}$ & Location & Key players & Summary \\
\hline $\begin{array}{l}\text { Saradha } \\
\text { Group } \\
\text { financial } \\
\text { scandal }\end{array}$ & 2013 & 40,000 & $\begin{array}{l}\text { West } \\
\text { Bengal }\end{array}$ & $\begin{array}{l}\text { Kunal Ghosh,Sudipto Sen, Madan } \\
\text { Mitra and many more }{ }^{[1][2][3]}\end{array}$ & $\begin{array}{l}\text { Financial scam caused by the collapse of a Ponzi scheme run by Saradha Group, a } \\
\text { consortium of over } 200 \text { private companies that was believed to be running collective } \\
\text { investment schemes popularly but incorrectly referred to as chit funds. }{ }^{[4][5][8][7]}\end{array}$ \\
\hline $\begin{array}{l}\text { Common } \\
\text { Wealth } \\
\text { Games Scam }\end{array}$ & 2010 & $\begin{array}{l}70,000 \text { Crore. (Rs } \\
70,000,000,0000)\end{array}$ & New Delhi & $\begin{array}{l}\text { Suresh Kalamadi, Sheila Dixit- } \\
\text { the then Chief Minister of the } \\
\text { State. }\end{array}$ & $\begin{array}{l}\text { It is estimated that out of Rs. } 70000 \text { crore spent on the Games, only half the said amount } \\
\text { was spent on Indian sportspersons. The Central Vigilance Commission, involved in probing } \\
\text { the alleged corruption in various Commonwealth Games-related projects, has found } \\
\text { discrepancies in tenders - like payment to non-existent parties, will-ful delays in execution of } \\
\text { contracts, over-inflated price and bungling in purchase of equipment through tendering - and } \\
\text { misappropriation of funds. }\end{array}$ \\
\hline $\begin{array}{l}\text { Indian coal } \\
\text { allocation } \\
\text { scam }^{[8]}\end{array}$ & 2012 & 185,591 & National & $\begin{array}{l}\text { Comptroller and Auditor General } \\
\text { of India, the coal ministry, many } \\
\text { electricity boards and private } \\
\text { companies }\end{array}$ & $\begin{array}{l}\text { coal blocks allotted, not auctioned, leading to estimated losses as per the Comptroller and } \\
\text { Auditor General of India[9[10][11] Supreme Court cancels all } 214 \text { coal blocks allocations since } \\
\text { 1993. Government to e-auction the coal blocks now. }{ }^{[12]}\end{array}$ \\
\hline $2 \mathrm{G}$ scam & 2008 & 176,000 & National & $\begin{array}{l}\text { Nira Radia, A. Raja, M. K. } \\
\text { Kanimozhi, many } \\
\text { telecommunications companies }\end{array}$ & $\begin{array}{l}\text { communication bandwidth auctioned for lower than market value.A. Raja and M. K. } \\
\text { Kanimozhi have been in Tihar Jail for } 15 \text { months and } 5 \text { months respectively. They have been } \\
\text { charge framed. }{ }^{[20][21]}\end{array}$ \\
\hline $\begin{array}{l}\text { Uttar Pradesh } \\
\text { food grain } \\
\text { scam }\end{array}$ & 2003 & $30,[22] 00,00,000$ & $\begin{array}{l}\text { Uttar } \\
\text { Pradesh }\end{array}$ & Mulayam Singh Yadav, Mayawati & $\begin{array}{l}\text { Food which the government purchased to give to the poor was instead sold on the open } \\
\text { market }{ }^{[23][24][25][26]}\end{array}$ \\
\hline
\end{tabular}

Source : https://en.wikipedia.org/wiki/List_of scandals in India

The anti-corruption waves in India has arguably helped to drive the Bharatiya Janata Party's (BJP) Narendra Modi and his National Democratic Alliance (NDA) government into power in the 2014 general election and also Aam Aadmi Party (AAP) came into the political scene with a promise to clean up government BJP government consistently raise their voices for the fight against corruption during the campaign trail, addressing mass crowds about "ABCD of corruption," that the Congress government are responsible for the listing numerous scams : "A for Adarsh, B for Bofors, C for CWG and D for Damad Ka Karobaar (,son-in-law's business, "e a reference to corruption allegations lodged against Robert Vadra, the son-in-law of Congress president Sonia Gandhi)."

\subsection{Anti corruption Laws \&Framework for fighting corruption:}

Indiae $\mathrm{s}$ history is filled up with number of anti-corruption measures and following punishments. The Rig Veda, a sacred Hindu text described as "the oldest literary monument of the Indo-European races," discusses the prevention of corruption and extortion. People were punished by Vishnu and Manu who accepted bribes and corrupt government officials with property penalty .To reduce \& to have a control at bribery and corruption, the law makers have thought of enacting Anti-Corruption Laws in India and protect the system from the jaws of corruption.

- IPC: In the nineteenth century, before the collapse of colonialism in India, Britain passed the Indian Penal Code to construct a proper legal criminal system. The Code had a chapter on ,Offences by Public Servants '. Sections 161 to 165 provided the legal framework to prosecute corrupt public servants. In the pre-independence period, the Indian penal Code (IPC) was the main tool to combat corruption in public life.

- Prevention of Corruption Act 1947: The Prevention of Corruption Act, 1947 did not redefine nor expand the definition of offences related to corruption the already existing IPC. Similarly, it has adopted the same definition of „Public Servant" as in the IPC. However the law defined a new offence ,criminal misconduct in discharge of official duty $^{\text {ee }}$ - for which enhanced punishment (minimum one year to maximum seven years) was stipulated. The Act also provided that the statement by bribe-giver would not subject him to prosecution. It was considered necessary to grant such immunity to the bribe-giver, who might have been forced by circumstances into giving a bribe.

- Prevention of Corruption Act, 1988: The prevention of Corruption Act 1988 consolidates the provisions of the Prevention of Corruption Act, 1947, the Criminal Law Amendment Act, 1952 and sections 161 to 165 of IPC.

\section{Volume 4 Issue 11, November 2015}




\section{International Journal of Science and Research (IJSR) \\ ISSN (Online): 2319-7064}

Index Copernicus Value (2013): 6.14 | Impact Factor (2014): 5.611

Besides, it has certain provisions intended to effectively combat corruption among public servants. The term „Public Servante is broadly defined and a new concept of „Public Duty ${ }^{e e}$ was introduced. Besides, trail on cases by Special Judges, enhancement of penalties on offences combating or incorporated to curbing corruption.

- Article 311 of the Indian Constitution: The Constitution of India reiterated the former Prevention of Corruption Act, 1947 provision that no civil servant can be prosecuted and punished by an authority subordinate to the one which made the original appointment While this provision was originally intended to protect the civil servants from harassment, it in fact turned out to be a hindrance in that sometimes no consent was given by the appointing authority.

- Prevention of Money Laundering Act, 2002: The Prevention of Money Laundering Act, 2002 (PMLA) forms the core of the legal framework put in place by India to combat money laundering. This Act empowers the Directorate of Enforcement, India and Financial Intelligence Unit, India; both agencies of the Government of India, to investigate and prosecute such persons who hold ill-gotten wealth in foreign countries and transfer their homeland through money launder in under this Act.

- Right to Information Act, 2005: Confidentiality in public administration breeds corruption, The Right to Information Act (RTI Act) has played a vital role in the fight against corruption in India. The RTI Act stipulates that citizens have the right to access government documents within 30 days from the filing of the request. Thereby, a mechanism of control of public spending has been granted to ordinary citizens The Right to Information Act, 2005 has been enacted aiming at ensuring, transparency, efficiency and accountability in public life. This is a revolutionary step towards the suppression of corruption from public life.

Above are the highlights of existing legal frame work for fighting corruption. India, like many other countries, had formed a number of offices circulating anti-corruption measures, such as in the Department of Personnel and Training the Administrative Vigilance Division, CBI, Vigilance Units in the Ministries and departments of the Government of India, disciplinary authorities, and the CVC . The Jan Lokpal Bill is also prominent step towards combating corruption. It aims to effectively deter corruption, compensate citizen grievances, and protect whistle-blowers. The Right to Information Act, 2005 has emerged as one of the most effective initiatives amongst the various measures taken by the government in fighting corruption.

\section{Literature Review}

The focus of literature review will be on corruption and anti corruption Act/ strategies in India.
Corruption can stand in the way of efficient governance; distort perceptions of procedural fairness and hinder economic growth (Myrdal 1968; Shleifer and Vishny 1993; Mauro 1995; Mo 2001). Bribes are often paid in awarding public contracts or receiving services faster (speed money).

A number of government commissions have noted corruption as being systematic in India because of the concentration of power among bureaucrats and politicians, "who flourished on the basis of mutual dependence and institutional abuse of power structures". (Kumar A 1999) Experts say people are not concerned with corruption on higher levels, instead worry about corruption "at the cutting edge level of administration", which they experience on a daily basis. (CMS India Transparency International India, 2008)

Type of bribery when often officials demand bribes for delivering services that citizens are entitled to get, like delivery of a passport or admission to hospital, School this type of bribes Basu (2011) calls harassment bribes . Though the official cannot legally deny the service, he can delay or aggravate delivery to the point where it becomes useless to the citizen. Harassment bribes are, although in themselves non distortionary, arguably welfare reducing since they need to be paid to receive entitled goods and services (Basu 2011).

A more fundamental root for the relative failure of anticorruption strategies is that they are ,more often limited to rhetoric, and are only rarely sustained (Wei 2001: 6). Wei suggests that this is because some political leaders fear the political risks associated with thorough and well-established reform of corrupt processes/practices and that the cost of creating significant reforms and achieving essential progress is often too expensive.

\section{Methodology of Study}

The main objectives of the study is to understand the existing anti corruptions strategies, \& why these measures \& initiatives of Indian government in combating corruption have not been able to give desired results . The study is mainly based on the secondary source in form of various research papers websites and ebooks along with the own observations regarding the same.

\section{Why initiatives are not effective in combing corruption}

While number of initiatives has been taken towards eliminating /minimizing corruption, these measures have not been able to achieve the desired results. The Indian government's track record in combating corruption has not been very effective. The main reason for this as per the survey (fig4.1) is delayed justice that weakens the effectiveness of the verdict, and political interference. Irrespective of the current and impending legislations, corruption levels are expected to remain at the current level. As per the survey of KPMG's bribery and corruption survey 2011 below mentioned are the reasons for poor enforcement. 


\section{International Journal of Science and Research (IJSR) \\ ISSN (Online): 2319-7064}

Index Copernicus Value (2013): 6.14 | Impact Factor (2014): 5.611

Key Reasons for poor enforcement

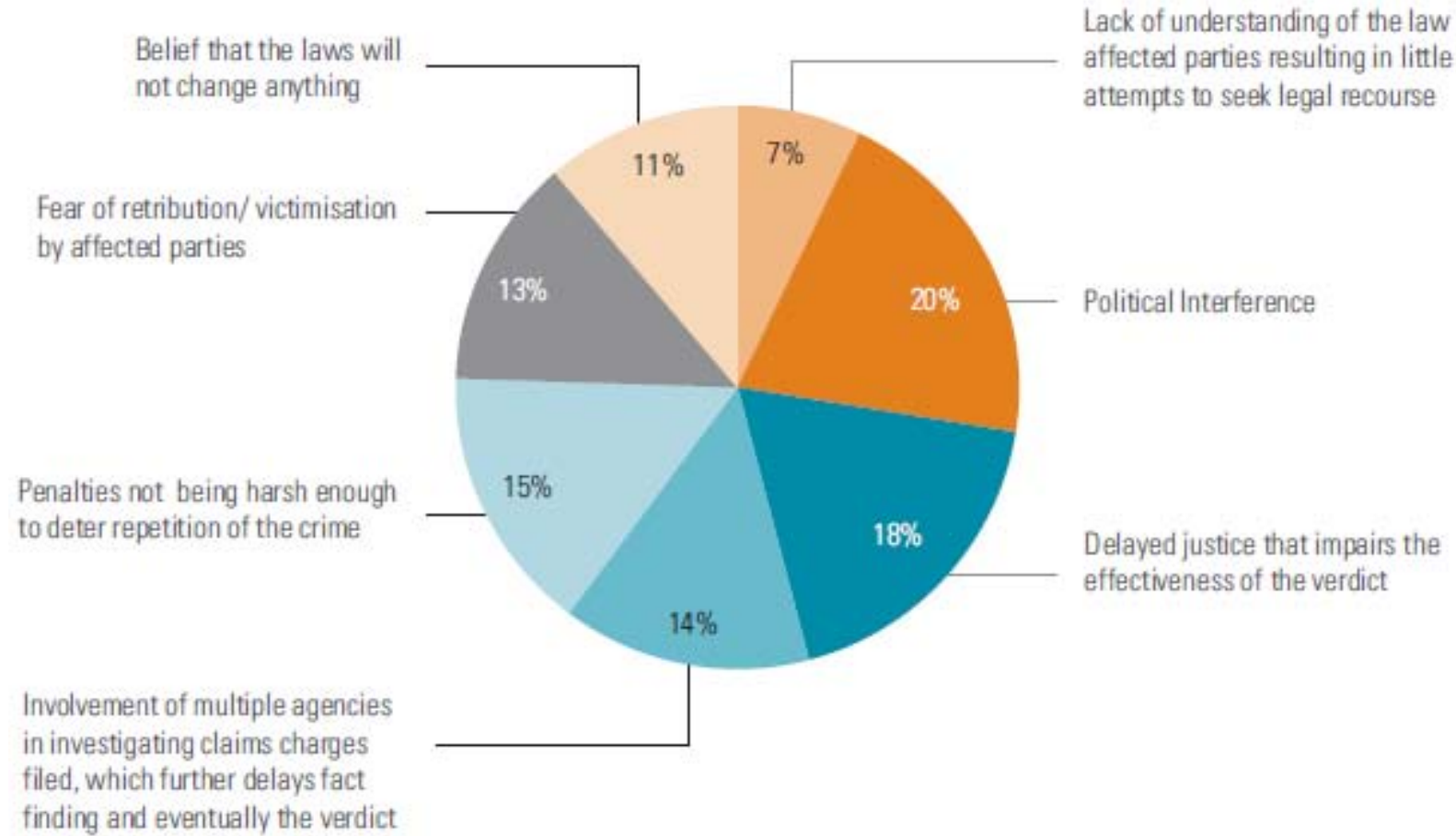

\section{Source: KPMG's Bribery and Corruption Survey 2011|}

The above data from KPMG bribery and corruption survey 2011 says that for a long time at different levels India has been facing governance challenges. Strict bureaucracy, complex laws and lengthy processes of the legal system discourage people from considering legal way out in corruption cases. Plenty of court cases in India are pending to be resolved. Inadequate infrastructural facilities and man power, lack of third party investigations were identified as factors for such delays. The legal framework around bribery and corruption lacks teeth:

- The Prevention of Corruption Act is a penal legislation in the process of decrease corruption and does not provide for any form of public participation.

- To protect whistleblowers CVC has not been provided with enforcement powers nor has it been made mandatory for the administrative authorities to act in accordance with with CVC's directives.

- The Lok Ayuktas can only recommend punishments do not have the powers to punish anyone \& and their recommendations are rarely acted upon.

- The regulation in India tends to focus on the bribe taker rather than the bribe payer.

- For protection of whistle blowers and witnesses, the lack of a legislation and adequate mechanism has often resulted in complaints not being made out of fear of reprisals or in complains being made on an anonymous basis which are then either ignored or not investigated properly, resulting in inaction for the same.

Such factors and lack of awareness \& restricted sphere of judiciary are responsible for anti corruption enforcement at its full scale which have made it tough for civil bodies and authorities to fight corruption.

\section{Conclusion}

Corruption is a stubborn problem; it is like diabetes, which can only be controlled, but not totally eliminated. To root out corruption completely from society may not be possible at all levels but it is possible to control it within tolerable limits. We need to make a comprehensive code of conduct for politicians, legislatures, bureaucrats control over electoral expenses, honest and dedicated persons in public life, \& such code should be strictly enforced to combat corruption. However the lack of implementation and monitoring of anticorruption strategies has raised questions on their effectiveness in practice. More independence should be given to Judiciary law and order should be allowed to work without political interference, and special courts should be set-up to take up such issues and speedy trial is to be promoted. To report potential bribery/ corruption issues a structured whistle blowing mechanism should be followed. NGOs and media can play a vital role, they should come forward to create awareness on laws and regulations \& against corruption in society and educate people to combat corruption.

India has indicated its commitment to fight with corruption by signing the G-20 Anti-corruption plan. However, the global environment is speedily changing and Indian regulations are aligning themselves to global anti-bribery and corruption laws and practices.

\section{References}

[1] A .Shleifer and R.Vishny, (1993) Corruption Quarterly Journal of Economics, 108(3), 599- 617.

[2] A Kumar, The Black Economy of India (Penguin Books, 1999) 


\section{International Journal of Science and Research (IJSR) \\ ISSN (Online): 2319-7064}

Index Copernicus Value (2013): 6.14 | Impact Factor (2014): 5.611

[3] Centre for Media Study Transparency International India, "Tii -Cms India Corruption Study 2007 with Focus on Bpl Households: National Report," (CMS India Transparency International India, 2008)

[4] 23 Encyclopedia Americana: A Library of Universal Knowledge 517 (1919). The Rig Veda dates back as early as 1200 B.C

[5] H.D.Lasswell, Encyclopedia of social sciences, volume 1, New York [U.S.A], Free Press, 1969, p690

[6] J.S Nye, corruption and political Development: A cost Benefit Analysis, The American Political Science Review, volume 61, No2, June 1967, p419

[7] J Svensson 2005. Eight questions about corruption. Journal of economic perspectives 19(3): 19-42

[8] K. Basu, (2011), "Why for a class of Bribes, the act of giving a bribe should be treated as Legal" Published in: Ministry of Finance Government of India Working Paper No1/2011 DEA

[9] KPMG_Bribery_Survey_Report_new.pdf, Survey on bribery and Corruption (2011)

[10] Myrdal (1968) Asian Drama: An Inquiry into the Poverty of Nations. New York: Twentieth Century Fund.

[11] P. Mauro, (1995) Corruption and growth Quarterly Journal of Economics 110(3), $681-712$

[12] P. Mauro, (2004) The persistence of corruption and slow economic growth.IMF Staff Papers, 51(1), 1-18.

[13] P. Mo, (2001) Corruption and economic growth Journal of Comparative Economics, 29(1), 66-79.

[14] Patibandla, Murali. "Economic Reforms and Institutions: Policy Implications for India." Economic and Political Weekly (1997): 1083-1090.

[15] Shiladitya Chakraborty, Public Services Reforms in India: A Fight Against corruption, published by Towards Freedom, pp 126 -129 (2013)

[16] S .Wei 2001. Corruption and globalization. Policy brief no. 79, April. Washington DC: Brookings Institution

\section{Websites Link :}

[17] http://www.lawctopus.com/academike/economic-scamsindia/

[18] https://www.kpmg.com/IN/en/IssuesAndInsights/Thoug htLeadership/KPMG_Bribery_Survey_Report_new.pdf

[19] http://trak.in/tags/business/2010/11/25/top-10corruption-scams-scandals-india/

[20] http://www.icgg.org/downloads/contribution07_andvig. pdf

[21] http://shodhganga.inflibnet.ac.in/bitstream/10603/8108/ 12/12_chapter\%203.pdf

[22] http://www.isid.ac.in/ pu/conference/dec_12_conf/Pape rs/TarunJain.pdf

[23] http://www.rediff.com/news/report/hazare-to-fast-onmarch-25-in-delhi/20120314.htm

[24] http://cvc.gov.in/NACSSummary.pdf

\section{Author Profile}

Shalini Kumar received the B.E \& MBA Degrees from BIT (Mesra) \& (IGNOU) respectively $\&$ having $8+$ years of versatile experience across diverse organizational domains with significant exposure in Teaching \& Academic administration. Presently she is Research Scholar at Techno India University in the Department of Humanities \& Social Sciences/Management her current research fields are work ethics and organizational culture. 